CrossMark \& click for updates

Cite this: Chem. Commun., 2015, 51, 10119

Received 21st April 2015, Accepted 12th May 2015

DOI: $10.1039 / c 5 c c 03301 b$

www.rsc.org/chemcomm

\section{Electrochromic polyoxometalate material as a sensor of bacterial activity}

\author{
Ana González, ${ }^{a}$ Natividad Gálvez, ${ }^{a}$ Miguel Clemente-León ${ }^{\mathrm{b}}$ and \\ Jose M. Dominguez-Vera*a
}

\begin{abstract}
Lactobacillus fermentum, a bacterium of human microbiota, acts as an electron donor for the electrochromic $\left[\mathrm{P}_{2} \mathrm{Mo}^{\mathrm{VI}}{ }_{18} \mathrm{O}_{62}\right]^{6-}$. Since the reductive capacity of $L$. fermentum correlates with its metabolic activity, the reaction with $\left[\mathrm{P}_{2} \mathrm{Mo}^{\mathrm{VI}}{ }_{18} \mathrm{O}_{62}\right]^{6-}$ affords a means of evaluating its activity. Following this logic, we have concluded that vancomycin severely affects the activity of $L$. fermentum whereas omeprazole does not.
\end{abstract}

Polyoxometalates (POMs) have attracted a lot of attention due to their applications in diverse fields such as catalysis, biomedicine and materials science. ${ }^{1-10}$ Their structures can be described as molecular fragments of close-packed metal oxides with the general formula $\left[\mathrm{X}_{x} \mathrm{M}_{m} \mathrm{O}_{y}\right]^{n-}$ (where $\mathrm{M}=\mathrm{Mo}, \mathrm{W}, \mathrm{V}$, etc. and $\mathrm{X}=\mathrm{P}, \mathrm{Si}$, As, etc. .). ${ }^{11}$

One of the most important properties of POMs, which gives rise to their main applications, is their ability to accept electrons yielding mixed-valence species. This ability means POMs are very good electrochromic materials. A living organism can be an electron donor for a POM, and this is of paramount interest because in such a case switching of the chromic properties of the POM can be directly related to a certain biological activity, i.e., to life itself.

Some microorganisms are known for their ability to reduce metal cations, which has been exploited for the eco-friendly synthesis of zero-valent metal nanoparticles. ${ }^{12-17}$ However, this property has not been exploited in other fields beyond the preparation of nanoparticles.

We want to open a new avenue: since the properties of metallic materials depend on the oxidation states of metal cations present in the structure, the possibility of using living organisms to reduce the metal cations in certain materials offers promising routes to develop new protocols for measuring their biological activity and to be used as a tool to establish an ex vivo experimental framework for testing the effect of certain drugs on the metabolism of the microorganisms. Detection and

\footnotetext{
${ }^{a}$ Departamento de Química Inorgánica, Facultad de Ciencias and Instituto de Biotecnología, Universidad de Granada, Spain. E-mail: josema@ugr.es

${ }^{b}$ Instituto de Ciencia Molecular, Universidad de Valencia, Spain
}

determination of bacterial activity are often performed in reference to toxic bacteria. However, the determination of healthy bacteria in some biological fluids and, in particular, the study of how some drugs can affect this healthy function are also of interest.

An approach based on switching of the electrochromic properties of a material in order to the monitor cell metabolism has been developed for the first time. We have studied how Lactobacillus fermentum is capable of acting as an electron donor for the electrochromic POM $\left[\mathrm{P}_{2} \mathrm{Mo}^{\mathrm{VI}}{ }_{18} \mathrm{O}_{62}\right]^{6-}$. It is well known that this probiotic bacterium has a positive effect on the maintenance of human health since it constitutes part of our natural microbiota, thus playing an important role in promoting the immune system activity, defence against infections and anti-inflammatory properties. This protocol can be extended to the observation of other reducing bacteria.

As the reductive ability of $L$. fermentum correlates directly to its bacterial activity (synthesis and secretion of extracellular reducing molecules), the protocol is useful for ex vivo screening to measure how specific drugs can affect the activity of the bacterium. Thus, the influence of the antibiotic vancomycin and the proton pump inhibitor omeprazole on the activity of this bacterium have been evaluated by simply monitoring the reductive power of L. fermentum with respect to $\left[\mathrm{P}_{2} \mathrm{Mo}^{\mathrm{VI}}{ }_{18} \mathrm{O}_{62}\right]^{6-}$ in the presence of these drugs. $\dagger$

The electrochromic POM $\left[\mathrm{P}_{2} \mathrm{Mo}^{\mathrm{VI}}{ }_{18} \mathrm{O}_{62}\right]^{6-}$ has been used to assess the activity of the bacterium $L$. fermentum. This POM is reduced by the addition of various specific number of electrons, leading to a family of mixed-valence $\mathrm{Mo}^{\mathrm{VI}} \mathrm{Mo}^{\mathrm{V}}$ species with a characteristic deep blue colour ("heteropoly blues"), which are easily detected by UV-vis spectroscopy. ${ }^{18,19}$

As shown in Fig. 1, upon incubating $\left[\mathrm{P}_{2} \mathrm{Mo}^{\mathrm{VI}}{ }_{18} \mathrm{O}_{62}\right]^{6-}$ in a culture of L. fermentum, a large band centred at $800 \mathrm{~nm}$ gradually develops, which confirms that the POM is reduced by the bacterium. It means that the redox capacity of the bacterium is at least higher than $0.5 \mathrm{~V} v s$. SCE, which is the potential at which $\left[\mathrm{P}_{2} \mathrm{Mo}^{\mathrm{VI}}{ }_{18} \mathrm{O}_{62}\right]^{6-}$ is reduced. ${ }^{20}$

Interestingly, the reductive power of L. fermentum is at its greatest under optimal bacterial proliferation conditions. 

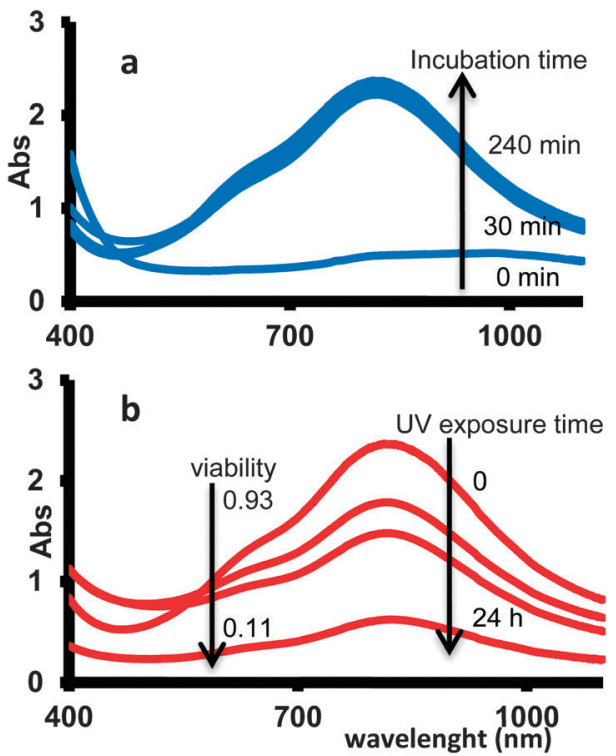

Fig. 1 (a) UV-vis spectra of supernatant solution obtained after incubation of $L$. fermentum with $\left[\mathrm{P}_{2} \mathrm{Mo}^{\mathrm{VI}}{ }_{18} \mathrm{O}_{62}\right]^{6-}$. The band at $800 \mathrm{~nm}$ increases with the incubation time. (b) UV-vis spectra of supernatant solution obtained after incubation of $L$. fermentum previously exposed to UV light with $\left[\mathrm{P}_{2} \mathrm{Mo}^{\mathrm{VI}}{ }_{18} \mathrm{O}_{62}\right]^{6-}$. The band at $800 \mathrm{~nm}$ decreases with the UV exposure time. Likewise, values of viability, measured as the ratio between live and dead bacteria, also decrease. The weaker the metabolic strength of bacteria, the smaller is the UV-vis band at $800 \mathrm{~nm}$.

A correlation between the biological strength and reductive power of the bacterium is evident: the stronger the metabolic strength of the bacterium, the greater is its reducing capacity. Furthermore, when a culture of L. fermentum is exposed to UV light, its capacity to reduce $\left[\mathrm{P}_{2} \mathrm{Mo}^{\mathrm{VI}}{ }_{18} \mathrm{O}_{62}\right]^{6-}$ decreases with time until it practically disappears (Fig. $1 \mathrm{~b}$ ). The damage and death caused by radiation have implications on the reducing capacity of the bacterial colony, measured in terms of viability. Therefore, the measurement of $L$. fermentum's capacity to reduce $\left[\mathrm{P}_{2} \mathrm{Mo}^{\mathrm{VI}}{ }_{18} \mathrm{O}_{62}\right]^{6-}$ is a direct evaluation of its metabolism strength.

On the other hand, when the reduction of $\left[\mathrm{P}_{2} \mathrm{Mo}^{\mathrm{VI}}{ }_{18} \mathrm{O}_{62}\right]^{6-}$ was tested in the absence of the bacterium, but in the presence of the extracellular supernatant solution generated by the cultivated bacterium, $\left[\mathrm{P}_{2} \mathrm{Mo}^{\mathrm{VI}}{ }_{18} \mathrm{O}_{62}\right]^{6-}$ was still reduced. From these observations, it can be concluded that $\left[\mathrm{P}_{2} \mathrm{Mo}^{\mathrm{VI}}{ }_{18} \mathrm{O}_{62}\right]^{6-}$ is reduced with the aid of extracellular bacterial reducing agents, while the observations also suggest the existence of a chemical site for binding $\left[\mathrm{P}_{2} \mathrm{Mo}^{\mathrm{VI}}{ }_{18} \mathrm{O}_{62}\right]^{6-}$ to the external surface of the bacterium, as occurs with other metalates. In this sense, Yamase et al. ${ }^{21}$ who were the first to observe the reduction of POMs by living organisms, concluded that reduction of some POMs by Staphylococcus aureus proceeds within cells, at the cytoplasmic membrane. However, in contrast to this, in L. fermentum, the reduction takes place at the extracellular level as demonstrated by the fact that the supernatant solution, containing secreted reducing-molecules, is also capable of reducing $\left[\mathrm{P}_{2} \mathrm{Mo}^{\mathrm{VI}}{ }_{18} \mathrm{O}_{62}\right]^{6-}$ and corroborated by transmission electron microscopy (TEM) images, which show reduced $\left[\mathrm{P}_{2} \mathrm{Mo}^{\mathrm{VI}}{ }_{18} \mathrm{O}_{62}\right]^{6-}$ both associated and non-associated with the bacterium (Fig. 2).

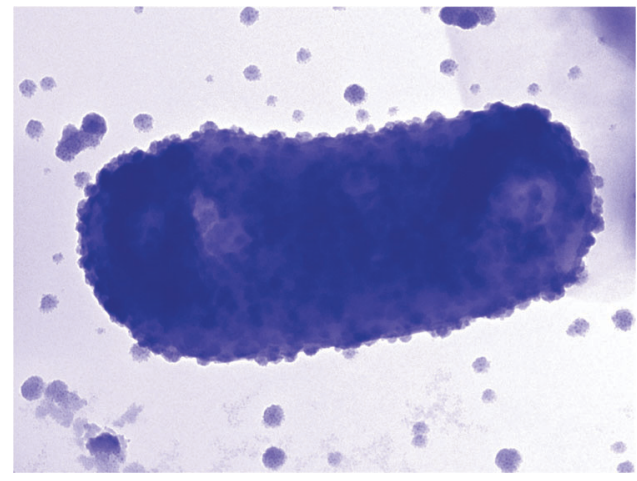

Fig. 2 TEM micrograph showing the presence of POM particles on the external surface of the bacterium and outside.

TEM studies of $L$. fermentum after incubation with $\left[\mathrm{P}_{2} \mathrm{Mo}^{\mathrm{VI}}{ }_{18} \mathrm{O}_{62}\right]^{6-}$ demonstrated the rod morphology typical of the Lactobacillus genus with large accumulations of nanoparticles on the external surface of the bacterium and outside (Fig. 2).

The existence of large particles surrounding the bacterium is especially well visualized by high-angle annular dark field-scanning transmission electron microscopy (HAADF-STEM). As shown in Fig. 3, the bacterium contains bright spherical particles of heterogeneous size distributions, between 20 and $100 \mathrm{~nm}$. To confirm the presence of the reduced POM around the bacterium, energy dispersive X-ray spectroscopy (EDX) experiments were performed. The results revealed the juxtaposition of molybdenum (in blue), phosphorous (in green) and the bacterial platform (Fig. 3). The particles do not seem to be confined at a specific bacterial site but associated with the broad biofilm, which is typical of L. fermentum..$^{22,23}$

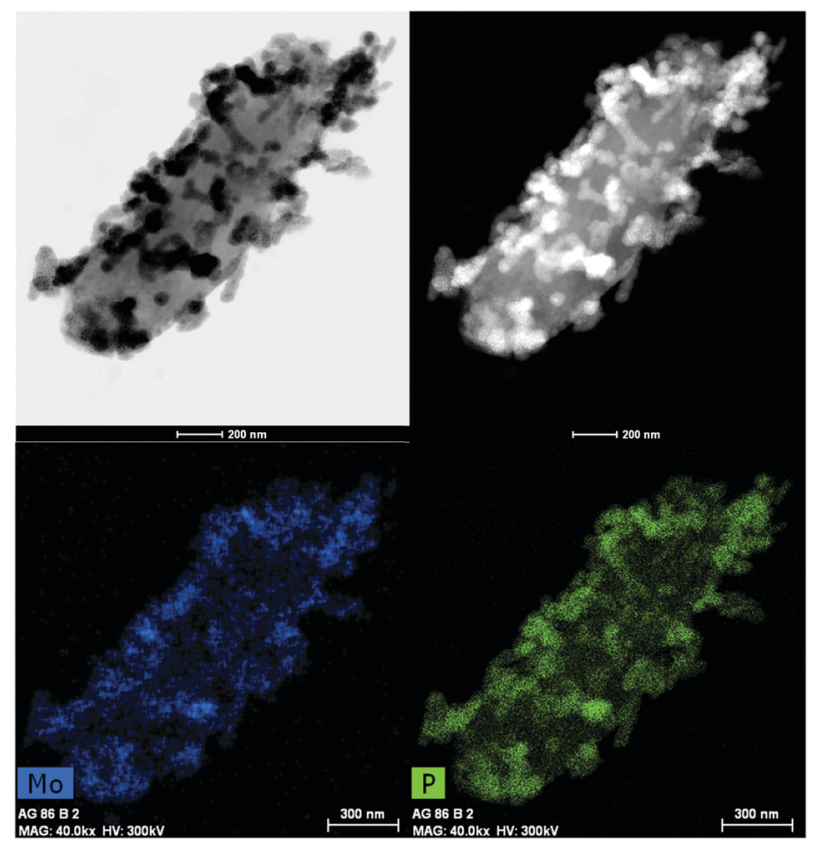

Fig. 3 (a) TEM micrograph showing the presence of particles on the external surface of the bacterium. (b) The HAADF-STEM micrograph of a single bacterium. ( $c$ and d) EDX compositional maps of Mo (blue) and P (green) collected over the whole HAADF-STEM image in (b). 
As the biological strength of $L$. fermentum correlates with its reducing capacity, the methodology we have developed based on the monitoring of the reduction of $\left[\mathrm{P}_{2} \mathrm{Mo}^{\mathrm{VI}}{ }_{18} \mathrm{O}_{62}\right]^{6-}$ serves to analyse how specific drugs can affect the activity of L. fermentum: the more damage the drug causes to the bacterium, the lower the reducing ability of the bacterium. This methodology is therefore useful for screening how some molecules impair L. fermentum activity. This is of interest in the context of an improved understanding of the side effects some drugs have on gut flora, of which $L$. fermentum is one of the main components.

Accordingly, we have evaluated the effect of vancomycin and omeprazole on the reducing capacity of L. fermentum. Both drugs are on the World Health Organization's list of essential medicines, the most important medications required by a basic health system. Vancomycin is an antibiotic used in the treatment of numerous bacterial infections. Orally administered vancomycin is indicated for intestinal infections. Omeprazole is a proton pump inhibitor used in the treatment of gastro-intestinal pathologies. There is some controversy for both vancomycin and omeprazole regarding the existence of side effects on the gut flora.

Experiments employing $L$. fermentum to reduce $\left[\mathrm{P}_{2} \mathrm{Mo}^{\mathrm{VI}}{ }_{18} \mathrm{O}_{62}\right]^{6-}$ were carried out in the presence of vancomycin or omeprazole. The effect on the reductive activity of the bacterium was monitored by observing the increase or decrease in the UV-vis absorbance band
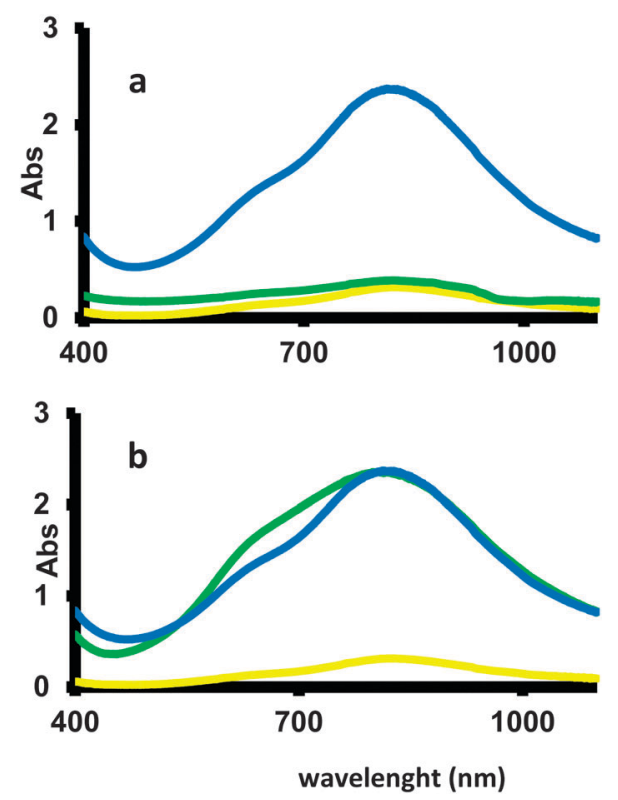

Fig. 4 (a) UV-vis spectrum for the reduction of $\left[\mathrm{P}_{2} \mathrm{MO}^{\mathrm{VI}}{ }_{18} \mathrm{O}_{62}\right]^{6-}$ by $L$. fermentum in the presence of vancomycin (green spectrum). Controls for the no reduction of $\left[\mathrm{P}_{2} \mathrm{Mo}^{\mathrm{Vv}}{ }_{18} \mathrm{O}_{62}\right]^{6-}$ by vancomycin (yellow spectrum) as well as reduction of $\left[\mathrm{P}_{2} \mathrm{Mo}^{\mathrm{V}_{1}}{ }_{18} \mathrm{O}_{62}\right]^{6-}$ by $L$. fermentum in the absence of vancomycin (blue line) are shown for comparison. Note that in the presence of vancomycin, L. fermentum loses its capacity of reducing $\left[\mathrm{P}_{2} \mathrm{Mo}^{\mathrm{VI}}{ }_{18} \mathrm{O}_{62}\right]^{6-}$ (green spectrum). (b) UV-vis spectra for the reduction of $\left[\mathrm{P}_{2} \mathrm{Mo}^{\mathrm{VI}}{ }_{18} \mathrm{O}_{62}\right]^{6-}$ by $L$. fermentum in the presence of omeprazole (green spectrum). Controls for the no reduction of $\left[\mathrm{P}_{2} \mathrm{Mo}^{\mathrm{VI}}{ }_{18} \mathrm{O}_{62}\right]^{6-}$ by omeprazole (yellow spectrum) as well as reduction of $\left[\mathrm{P}_{2} \mathrm{Mo}{ }_{18} \mathrm{O}_{62}\right]^{6-}$ by $L$. fermentum in the absence of omeprazole (blue line) are shown for comparison. Note that in the presence of omeprazole, L. fermentum does not lose its capacity of reducing $\left[\mathrm{P}_{2} \mathrm{MO}^{\mathrm{Vl}}{ }_{18} \mathrm{O}_{62}\right]^{6-}$ (green spectrum). centred at $800 \mathrm{~nm}$ corresponding to the reduced forms of $\left[\mathrm{P}_{2} \mathrm{Mo}^{\mathrm{VI}}{ }_{18} \mathrm{O}_{62}\right]^{6-}$. As shown in Fig. 4, the presence of vancomycin drastically affects the reducing power of $L$. fermentum. Thus, even in the presence of just millimolar concentrations of vancomycin, the reductive ability of the bacterium is almost negligible.

However, the presence of omeprazole does not seem to affect the ability of $L$. fermentum to reduce the POM $\left[\mathrm{P}_{2} \mathrm{Mo}^{\mathrm{VI}}{ }_{18} \mathrm{O}_{62}\right]^{6-}$, since the large band in the UV-vis spectrum that represents the reduced forms barely changes, even at high concentrations of omeprazole (Fig. 4).

In conclusion, L. fermentum acts as an electron donor for the electrochromic POM $\left[\mathrm{P}_{2} \mathrm{Mo}^{\mathrm{VI}}{ }_{18} \mathrm{O}_{62}\right]^{6-}$. The method developed in this study can be used to measure L. fermentum activity and to characterise its behaviour in the presence of certain drugs, such as the antibiotic vancomycin and the proton-pump inhibitor omeprazole. Thus, by using this method we have concluded that the antibiotic vancomycin severely affects the bacterial activity of L. fermentum, whereas omeprazole does not. This protocol can be extended to the characterisation of other metal-reducing bacteria (with either negative or positive effects on human health) in the field of medical analysis. In this sense, the future prospect of this work is to create new nano-devices based on the approach and methodology described in this communication for screening the ex vivo activity of new antibacterial materials.

This work was funded by MINECO and FEDER (project CTQ2012-32236).

\section{Notes and references}

$\dagger$ Experimental: $\mathrm{Na}_{6}\left[\mathrm{P}_{2} \mathrm{Mo}^{\mathrm{VI}}{ }_{18} \mathrm{O}_{62}\right] \cdot\left(\mathrm{H}_{2} \mathrm{O}\right)_{24}$ was synthesized as reported in the literature. ${ }^{24}$ The purity of the compound was confirmed by the IR spectrum, which showed the characteristic bands of the polyanion. IR (KBr pellet, $\left.\mathrm{cm}^{-1}\right)$ : 1078 ( $\left.\nu \mathrm{P}-\mathrm{O}, \nu s.\right), 941(\nu \mathrm{Mo}=\mathrm{O}, v s),. 906(\nu \mathrm{Mo}-\mathrm{O}-\mathrm{Mo}, \mathrm{w})$, 778 ( $\nu$ Mo-O-Mo, vs.).

L. fermentum bacteria were grown in anaerobiosis conditions in a synthetic medium at $37{ }^{\circ} \mathrm{C}$ with orbital agitation for $24 \mathrm{~h}$ in an initial concentration of $1 \mathrm{mg}$ bacteria in $1 \mathrm{~mL}$ of medium. The synthetic medium consisted of $\left(\mathrm{g} \mathrm{L}{ }^{-1}\right) \mathrm{Na}_{2} \mathrm{HPO}_{4}-5.0, \mathrm{KH}_{2} \mathrm{PO}_{4}-6.0$, trisammonium citrate -2.0 , sucrose $-50.0, \mathrm{MgSO}_{4}-1.0$ and trace elements solution - $10 \mathrm{ml}$ (consisting of $\left(\mathrm{g} \mathrm{L}^{-1}\right)$ : $\mathrm{MnSO}_{4}-2.0, \mathrm{CoCl}_{2}-1.0, \mathrm{ZnCl}_{2}-$ 1.0 dissolved in $0.1 \mathrm{~N} \mathrm{HCl}$ solution). The medium with an initial $\mathrm{pH} 6.7$ was sterilized at $121{ }^{\circ} \mathrm{C}$. The final $L$. fermentum cell concentration was $3.3 \times 10^{8} \mathrm{CFU} \mathrm{mL}{ }^{-1}$, which was used for all the experiments.

POM reduction by the bacterium: $100 \mu \mathrm{L}$ of a $10 \mathrm{mM}$ stock solution of $\left[\mathrm{P}_{2} \mathrm{Mo}^{\mathrm{VI}}{ }_{18} \mathrm{O}_{62}\right]^{6-}$ was added to $900 \mu \mathrm{L}$ of $L$. fermentum culture to obtain a final concentration of $1 \mathrm{mM}$ of $\left[\mathrm{P}_{2} \mathrm{Mo}^{\mathrm{VI}}{ }_{18} \mathrm{O}_{62}\right]^{6-}$. Bacteria with POM were incubated for $24 \mathrm{~h}$ and then centrifuged. L. fermentum's ability to reduce the POM was measured at 30, 60, 240 and $1440 \mathrm{~min}$ of incubation by UV-vis spectroscopy through the apparition of a band centred at $800 \mathrm{~nm}$ due to reduced POM forms. A control of culture media with no bacteria reductive activity was included.

L. fermentum culture exposed to UV light: 3 bacteria culture aliquots of $900 \mu \mathrm{L}$ were exposed to UV light for 60, 240 and $1440 \mathrm{~min}$ before the incubation at $37^{\circ} \mathrm{C}$. After UV exposition, the cultures were incubated for $24 \mathrm{~h}$ at $37{ }^{\circ} \mathrm{C}$ with orbital agitation and then $100 \mu \mathrm{L}$ of a $10 \mathrm{mM}$ stock solution of $\left[\mathrm{P}_{2} \mathrm{Mo}^{\mathrm{VI}}{ }_{18} \mathrm{O}_{62}\right]^{6-}$ was added. After centrifugation, the reductive activity was measured by the UV-vis absorbance band centred at $800 \mathrm{~nm}$ of the supernatant solution. A control of no UV light exposed culture was included.

Viability of the bacterial colony was defined as the ratio between live and dead bacteria, measured by flow cytometry. Values of $0.93,0.70$, 0.63 and 0.11 were obtained from the different UV exposed experiments at $0,60,240$ and $1440 \mathrm{~min}$.

Vancomycin and omeprazole effect on the reducing capacity: vancomycin and omeprazole in a final concentration of $0.2 \mathrm{mg} \mathrm{mL}^{-1}$ were 
added to two independent cultures. The cultures were incubated for $24 \mathrm{~h}$ at $37{ }^{\circ} \mathrm{C}$ with orbital agitation and then $100 \mu \mathrm{L}$ of a $10 \mathrm{mM}$ stock solution of $\left[\mathrm{P}_{2} \mathrm{Mo}^{\mathrm{VI}}{ }_{18} \mathrm{O}_{62}\right]^{6-}$ was added. The reductive activity in the presence of each drug was measured at $4 \mathrm{~h}$ by the UV-vis absorbance band centred at $800 \mathrm{~nm}$ at the supernatant solution obtained after centrifugation. Controls for the reduction of $\left[\mathrm{P}_{2} \mathrm{Mo}^{\mathrm{VI}}{ }_{18} \mathrm{O}_{62}\right]^{6-}$ by L. fermentum with no drugs and reduction of $\left[\mathrm{P}_{2} \mathrm{Mo}^{\mathrm{VI}}{ }_{18} \mathrm{O}_{62}\right]^{6-}$ by the drugs with no bacteria were included.

Viability values corroborated the effect of each drug of L. fermentum. Thus, almost null viability (0.07) was obtained for the experiment done in the presence of vancomycin whereas a value close to the control (in the absence of drug) was obtained for the experiment done in the presence of omeprazole (0.91).

Electronic microscopy: for TEM grid preparation a drop of $L$. fermentum after incubation with $\left[\mathrm{P}_{2} \mathrm{Mo}^{\mathrm{VI}}{ }_{18} \mathrm{O}_{62}\right]^{6-}$ was placed onto a carbon-coated $\mathrm{Cu}$ grid (200 mesh) and was blotted with filter paper. Samples were observed under a FEI TITAN G2 microscope and HAADF-STEM and EDX map were done using the same equipment.

1 M. T. Pope and A. Muller, Angew. Chem., Int. Ed. Engl., 1991, 30, 34. 2 N. Mizuno and M. Misono, Chem. Rev., 1998, 98, 199.

3 S. Omwoma, W. Chen, R. Tsunashima and Y.-F. Song, Coord. Chem. Rev., 2014, 258-259, 58.

4 M. Vazylyev, D. Sloboda-Rozner, A. Haimov, G. Maayan and R. Neumann, Top. Catal., 2005, 34, 93.

5 T. Yamase, Prog. Mol. Subcell. Biol., 2013, 54, 65.

6 B. Hasenknopf, Front. Biosci., 2005, 10, 275.

7 R. Neumann, NATO Sci. Ser., II, 2003, 98, 327.

8 D. E. Katsoulis, Chem. Rev., 1998, 98, 359.
9 J. M. Clemente-Juan, E. Coronado and A. Gaita-Arino, Chem. Soc. Rev., 2012, 41, 7464.

10 E. Coronado, C. Gimenez-Saiz and C. Gomez-Garcia, Coord. Chem. Rev., 2005, 249, 1776.

11 M. T. Pope, Heteropoly and Isopolyoxometalates, Springer, Berlin, 1983.

12 V. Bansal, A. Bharde, R. Ramanathan and S. K. Bhargava, Adv. Colloid Interface Sci., 2012, 179-182, 150.

13 A. K. Suresh, D. A. Pelletier, W. Wang, M. L. Broich, J. W. Moon, B. Gu, D. P. Allison, D. C. Joy, T. J. Phelps and M. J. Doktycz, Acta Biomater., 2011, 7, 2148.

14 P. Mukherjee, S. Senapati, D. Mandal, A. Ahmad, M. I. Khan, R. Kumar and M. Sastry, ChemBioChem, 2002, 3, 461.

15 P. Mukherjee, A. Ahmad, D. Mandal, S. Senapati, S. R. Sainkar, M. I. Khan, R. Ramani, R. Parischa, P. V. Ajayakumar, M. Alam, M. Sastry and R. Kumar, Angew. Chem., Int. Ed., 2001, 40, 3585.

16 S. K. Das, A. R. Das and A. K. Guha, Langmuir, 2009, 25, 8192.

17 R. Ramanathan, M. R. Field, A. P. O'Mullane, P. M. Smooker, S. K. Bhargava and V. Bansal, Nanoscale, 2013, 5, 2300.

18 E. Paconstaninum, Chem. Soc. Rev., 1989, 18, 1.

19 T. R. Zhang, W. Feng, R. Lua, C. Y. Bao, X. T. Zhang, T. J. Li, Y. Y. Zhao and J. N. Yao, Mater. Chem. Phys., 2002, 78, 116.

20 E. Papaconstantinou and M. T. Pope, Inorg. Chem., 1967, 6, 1152.

21 M. Inoue, T. Suzuki, Y. Fujita, M. Oda, N. Matsumoto and T. Yamase, J. Inorg. Biochem., 2006, 100, 1225.

22 M. Martín, F. Carmona, R. Cuesta, D. Rondón, N. Gálvez and J. M. Dominguez-Vera, Adv. Funct. Mater., 2014, 24, 3489.

23 F. Carmona, M. Martin, N. Galvez and J. M. Dominguez-Vera, Inorg. Chem., 2014, 53, 8565.

24 R. Strandberg, Acta Chem. Scand., Ser. A, 1975, 29, 350. 